IRA-International Journal of Applied Sciences ISSN 2455-4499; Vol.04, Issue 02 (2016)

Institute of Research Advances

Pg. no. 246-258

http://research-advances.org/index.php/IRAJAS

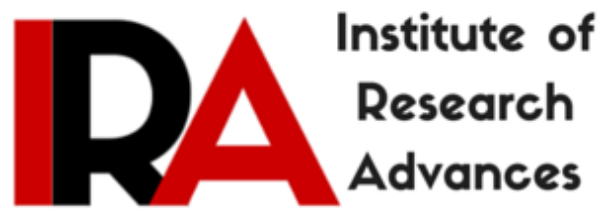

\title{
Evaluation of Antibacterial Activity of Solanum Xantocarpum SCH \& WEND (Fruit) Against Pathogens Isolated From Diabetic Foot Ulcer
}

\author{
${ }^{1}$ Shubha. K S, ${ }^{2}$ Lakshmidevi. N \\ $\mathbf{1 , 2}$ Department of Studies in Microbiology, University of Mysore, \\ Manasagangothri, Mysore-570 006, India.
}

Type of Review: Peer reviewed.

DOI: http://dx.doi.org/10.21013/jas.v4.n2.p5

\section{How to cite this paper:}

K S, S., \& N, L. (2016). Evaluation of Antibacterial Activity of Solanum Xantocarpum SCH \& WEND (Fruit) Against Pathogens Isolated From Diabetic Foot Ulcer. IRAInternational Journal of Applied Sciences (ISSN 2455-4499), 4(2), 246-258. doi:http://dx.doi.org/10.21013/jas.v4.n2.p5

(C) Institute of Research Advances

\section{(cc) EY-NC}

This work is licensed under a Creative Commons Attribution-Non Commercial 4.0 International License subject to proper citation to the publication source of the work.

Disclaimer: The scholarly papers as reviewed and published by the Institute of Research Advances (IRA) are the views and opinions of their respective authors and are not the views or opinions of the IRA. The IRA disclaims of any harm or loss caused due to the published content to any party. 


\section{ABSTRACT}

In the present study efficacy of various solvent extracts of $S$. xantocarpum fruit was assed against six pathogenic bacteria Proteus, E. coli, Klebsiella, Pseudomonas, Enterobacter and S. aureus, isolated from diabetic foot ulcer. Among the different extracts ethyl acetate showed highest activity in terms of inhibitory zone against E. coli, where as in ethanol extract significant activity was seen against Enterobacter.

Key words: Pathogens, antimicrobial activity, Solanum xantocarpum fruit.

\section{Introduction}

The medicinal plants have been used to cure diseases since antiquity. Plants still constitute one of the major sources of drug in modern as well as traditional medicine throughout the world [1]. Over 25\% of prescribed medicines in industrialized countries derived directly or indirectly from plants [2]. However, plants used in traditional medicines are still understudied, particularly in clinical microbiology [3]. In developing countries where medicines are quite expensive, investigation on antimicrobial activities from ethanomedicine plants may still be needed [4,5]. Several plants were known to possess antimicrobial properties in the literature. In the present study, we have selected $S$. xantocarpum fruit to claim to possess promising antimicrobial effects on the infected diabetic foot ulcer.

\section{Materials and Methods}

\section{Plant material collection}

Fresh healthy fruit of $S$. xantocarpum. Sch \& Wend were collected in and around of Mysore district, Karnataka, India. These were washed thoroughly 2-3 times with running tap water and once with sterile water, and then they were dried in shade. The taxonomic identification of these plant species was determined at National Ayurveda Dietetics Research Institute, Bangalore, Karnataka, India ( $S$. xantocarpum. Sch \& Wend. Voucher no. RRCBI-3721 The plant material were powered to 100-120 mesh in an apex grinder (Apex constructions, London) and stored.

\section{Test microorganisms}

The test organisms used were isolated from diabetic foot ulcer viz., Proteus, E. coli, Klebsiella, Pseudomonas, Enterobacter and S. aureus. The bacterial cultures were maintained on NAM respectively.

\section{Preparation of aqueous extract}

Fifty grams of fruit of S. xantocarpum were macerated with $100 \mathrm{ml}$ sterile distilled water in a blender for $10 \mathrm{~min}$. The macerate was first filtered through double layered muslin cloth and centrifuged at $4000 \mathrm{rpm}$ for $30 \mathrm{~min}$. The supernatant was filtered through Whatman No.1 filter paper and heat sterilized at $121^{\circ} \mathrm{C}$ for $30 \mathrm{~min}$. The extracts were preserved aseptically in brown bottles at $4^{\circ} \mathrm{C}$ until further use.

\section{Preparation of solvent extract}

Twenty grams of the powered plant materials were loaded in the thimble of Soxhlet apparatus. It was fitted with appropriate size round bottom flask and plant material was extracted with $150 \mathrm{ml}$ of pet ether (Merck, Darmstadt) by Soxhlet apparatus [6]. Constant heat was provided by Mantox heater for recycling the solvent. After complete extraction, the extract in the round bottom flask was transferred into sterile dry Petri plate and the solvent was evaporated. The sediment was scrapped off, and preserved at $4^{\circ} \mathrm{C}$ in airtight bottles until further use. Similar procedure was followed for other. 


\section{Antibacterial activity by agar well diffusion method}

Antibacterial activity by agar well diffusion method was carried out as per the methods of [7], briefly the bacterial suspension was adjusted to $0.5 \mathrm{Mc}$ Farland. About $15-20 \mathrm{ml}$ of NAM was poured in the sterilized petridish and allowed to solidify. Bacterial suspension of $100 \mu 1$ was pipetted and spread using spreader for the bacterial lawn preparation. Well of $6 \mathrm{~mm}$ diameter and about $2 \mathrm{~cm}$ apart were punched in the culture medium by cork borer. For each well 500 and $750 \mu \mathrm{g}$ (in the concentration of 0.5 and 0.75 $\mathrm{mg} / \mathrm{ml}$ ) of plant extract were loaded. Sterile DMSO was used as negative control, Kanamycin served as positive control. Plates were kept at $4^{\circ} \mathrm{C}$ for $30 \mathrm{~min}$ for the diffusion of plant extract. Plates were incubated at $37^{\circ} \mathrm{C}$ for $24 \mathrm{~h}$. Antibacterial activity was evaluated by measuring the inhibition zone after 24 h.

\section{Antibacterial activity by disc diffusion method}

The different solvent extracts were tested for antibacterial activity by disc diffusion method [8,9]. Bacterial suspension of $100 \mu \mathrm{l}$ containing $2.0 \times 10^{6} \mathrm{CFU} / \mathrm{ml}$ was pipetted and spread using spreader for bacterial lawn preparation in the previously prepared sterilized solidified NAM plates. Sterile filter paper discs of $6 \mathrm{~mm}$ diameter were impregnated with 0.01 and $0.02 \mathrm{mg} / \mathrm{ml}$ of plant extract $(10$ and $20 \mu \mathrm{g}$ concentration). The plates were kept at $4^{\circ} \mathrm{C}$ for $30 \mathrm{~min}$ for the diffusion of the plant extracts [10]. The plates were incubated at $37^{\circ} \mathrm{C}$ for $24 \mathrm{~h}$. The diameters of the inhibition zones were measured in millimeters. All the tests were performed in triplicates. Kanamycin $(30 \mu \mathrm{g})$ served as positive control and $10 \%$ Dimethyl sulfoxide (DMSO) serve as negative control.

\section{Determination of minimum inhibitory concentration}

The minimum inhibition concentration (MIC) was carried out by broth dilution method. $0.5 \mathrm{ml}$ (0.5 Mc Farland) of bacterial suspension was inoculated aseptically $10-0.0195 \mathrm{mg} / \mathrm{ml}$ of plant extract was added, this tube was considered as stock solution $\left(10^{-1}\right)$, and then this is serially diluted up to $10^{-8}$ dilution factor. After serial dilution, the tubes were tapped for uniform distribution of bacteria and plant extract. All the tubes were kept for incubation for $24 \mathrm{~h}$ at $37^{\circ} \mathrm{C}$. Similar procedure was adapted for remaining test bacterial suspensions [10]. Inhibition of bacterial growth was determined by measuring the absorbance at $465 \mathrm{~nm}$ using UV-visible Spectophotometer (Hitachi U-2000, Japan) against negative control. The minimum concentration of the organisms was determined as the MIC. The percentage of inhibition was calculated according to the formula.

Percent growth inhibition $=\left[\left(\mathrm{A}_{\text {control }}-\mathrm{A}_{\text {test }}\right) \mathrm{A}_{\text {control }}\right.$

\section{Results}

\section{Well method}

In the present study, results of inhibition zone in the well diffusion method using the solvent extract fruit of $S$. xantocarpum viz., pet ether, chloroform, ethyl acetate, ethanol and aqueous extract against control showed significant inhibition zone against six bacteria (E. coli, Proteus, Klebsiella, Pseudomonas, Enterobacter, S. aureus) tested compared to the standard antibiotic drug $30 \mathrm{mg}$ Kanamycin. The standard control exhibited inhibition of E. coli, Klebsiella and S. aureus by $10 \mathrm{~mm}, 8$ $\mathrm{mm}$ and $3 \mathrm{~mm}$ respectively. Proteus, Pseudomonas, Enterobacter was not inhibited by the standard drug (Kanamycin) (Table 1, Figs.1, 1a and 1b).

Aqueous extract of $S$. xantocarpum fruit at $0.5 \mathrm{mg} / \mathrm{ml}$ concentration did not inhibited the test bacterial isolates, however ethyl acetate, the only solvent inhibited E. coli, the zone of inhibition was 11.3. 
Aqueous fruit $S$. xantocarpum extract at $0.75 / \mathrm{ml} \mathrm{mg} \mathrm{concentration} \mathrm{inhibited} \mathrm{Enterobacter} \mathrm{and} S$. aureus by 9.6 and $12.6 \mathrm{~mm}$ respectively. Whereas pet ether and chloroform did not show inhibition. Ethyl acetate showed highest inhibition zone for E. coli (14.3) least inhibition zone for Klebsiella (11.0) and S. aureus (11.0) and Ethanolic extract also exhibited the zone of inhibition of E. coli (11.0), Proteus (12.3 $\mathrm{mm})$, Pseudomonas $(9.6)$ and Enterobacter $(18 \mathrm{~mm})$. Highest inhibition zone for Enterobacter $(18 \mathrm{~mm})$ and least inhibition zone for Pseudomonas $(9.6 \mathrm{~mm}$ ) (Table 1, Fig.1b and 1c).

\section{Disc method}

The efficacy of various solvent extracts of $S$. xantocarpum fruit against the isolated pathogenic bacteria has not shown any inhibition zone at $0.01 \mathrm{mg} / \mathrm{ml}$ concentration. The aqueous extract also did not exhibit any inhibition zone at this concentration against standard. Whereas in $0.02 \mathrm{mg} / \mathrm{ml}$ concentration, ethanol had exhibited zone of inhibition against Klebsiella and S. aureus with $3.6 \mathrm{~mm}$ and $8.0 \mathrm{~mm}$ respectively. But rest of the extracts viz., pet ether, chloroform, ethyl acetate has not showed any activity against bacteria. Aqueous extract has shown zone of inhibition against Proteus only with $6.0 \mathrm{~mm}$ (Table 2, Fig. $2 \mathrm{a}$ and $2 \mathrm{~b})$.

\section{Minimum Inhibitory Concentration (MIC)}

The MIC was carried out for only alcohol and ethyl acetate extracts as these had given very effective results against the foot ulcers pathogens. Solanum xanthocarpum fruit has shown the MIC of test organisms viz., E. coli $(0.5 \mathrm{mg} / \mathrm{ml})$, Proteus $(0.5 \mathrm{mg} / \mathrm{ml})$, Pseudomonas $(0.75 \mathrm{mg} / \mathrm{ml})$ and Enterobacter $(0.125 \mathrm{mg} / \mathrm{ml})$ concentration. (Table 3, Fig. 3a).

Ethyl acetate extract of. Solanum xanthocarpum fruit has shown the MIC for E. coli $(0.067$ $\mathrm{mg} / \mathrm{ml})$ which is found to be most effective against E. coli, Klebsiella $(0.75 \mathrm{mg} / \mathrm{ml})$, Pseudomonas $(0.25$ $\mathrm{mg} / \mathrm{ml})$ and $S$. aureus $(0.75 \mathrm{mg} / \mathrm{ml})$ concentration.

\section{Discussion for agar well diffusion method}

Antibacterial activity of the fruit of $S$. xantocarpum and were evaluated in vitro against six bacterial species. They were frequently found in diabetic foot ulcers. The aqueous and solvent extracts of the plant tested in the present study showed varied level of antibacterial activity. The results that were obtained show that the standard Kanamycin exhibited the zone inhibition against E. coli, Klebsiella and $S$. aureus. Similarly [11] have used amoxicillin as the standard and have recorded the zone of inhibition against E. coli, Shigella dysenteriae, Pseudomonas aeruginosa, Salmonella typhi, Yersinia, Enterocolitica, K. pnuemonia, and $P$. vulgaris. Concordantly [12] have reported that tetracycline that was taken as control have shown the inhibition zone against gram +ve bacteria i.e., B. cereus and Gram -ve bacteria Enterobacter aerogenes, E. coli, Klebsiella pneumonia and Acromonas hydrophila.

Aqueous extracts did not show the zone of inhibition and found that it was ineffective against the pathogenic bacteria. Similarly [13] have also reported that aqueous extracts were least effective against the B. cereus, E. coli, S. aureus, Pseudomonas aeruginosa, A. niger, A. flavus, $R$. stolonifer, $F$. oxysporum. However, [14] has reported that the ethanol and aqueous extracts of five Nigerian medicinal plants had broad spectrum of antimicrobial activity on Gram+ve and Gram -ve bacteria which responded to the inhibition activity of plant extract.

\section{Discussion for disc method}

An herbal remedy has been accompanied since a long time to the human kind and they continued to be the rich resource of therapeutic agent. It is anticipated that the active chemical component of the plants with the efficient antibacterial property is exploited for treating bacterial infections. Some of the 
phytochemical preparation with more flavonoids content is reported by many researchers which exhibit antibacterial activity $[15,16,17,18$, and 19$]$.

In the present investigation, the disc diffusion method was performed for E. coli, Proteus, Klebsiella, Pseudomonas, S. aureus against plant extracts. The standard drug has shown the inhibitory property for E. coli, Klebsiella, S. aureus during the present investigation in concordance with [20]; where they have tried with vancomycin, erytromycine and nystain. Presently, the fruit in aqueous and ethanolic extracts have inhibited Proteus, Klebsiella, S. aureus. [20] and [21] have also recorded the inhibition of Proteus, Klebsiella, S. aureus. Fruit of S. xantocarpum at $1 \mathrm{mg}$ and $2 \mathrm{mg}$ has shown the inhibition property chloroform and Ethanolic extract respectively, where Pseudomonas and S. aureus inhibited to greater extent. Similar results have been recorded by many researchers $[10,21]$. Similarly, the observation made by researchers with solvent extract of leaves of Bauhinia recemosa, leaf extract of Moringa olifera, seed, leaf, fruit, bark, steam of Acacia arabica (leaf), Eucalyplus globules (leaves), Helicteres isora (fruit), Aegle marmelos (leaves) Azadirachta indica (leaves) Caeselpinia bonducella (seed), Margifera indica (bark), Anonna squamosa (fruit), Jatropha careus (stem), Delonie regia (bark) $[21,22]$.

\section{Discussion for MIC}

The MIC of the ethanol and ethyl acetate extract inhibiting concentration value of the plant extracts are shown in Table 3. Solanum xanthocarpum fruit was found to be more effective in inhibiting Enterobacter at $0.75 \mathrm{mg} / \mathrm{ml}$ concentration, Klebsiella and S. aureus exhibited the resistance at 0.5 and $0.125 \mathrm{mg} / \mathrm{ml}$ concentration. Similar results were observed in the ethanol extract of Ocimum sanctum, Aegle marmelos and Adhatoda vasica [23].

The ethyl acetate extracts of $S$. xanthocarpum fruit has exhibited a range of MIC against the test organisms in the present study. Solanum xanthocarpum fruit exhibited more effectiveness in inhibiting $E$. coli at a very low concentration. The results were contrary to the findings of [24]. Proteus and Enterobacter were found resistant to the ethyl acetate extract of $S$. xanthocarpum fruit. This was also observed in the Toona ciliate roemer by [25] against Klebsiella and S. aureus organisms.

\section{REFERENCES:}

1. Suri., R K, Chuaudhari., D C, Jaffer., R (1992). Commercially important medicinal plants from forests. Journal Eco. Bot. Phytochemistry. 3(2): 129-140.

2. Newman., D J, Cragg., G M, Snader., K M (2000). The influence of Natural products upon Drug Discovery. Nat Prod Rep; (17): 175-285.

3. Kirby., G C (1996). Medicinal plants and the control of parasites. Trans Roy Soc Trop Med Hyg (90): 605-609.

4. Cowan., M. M. 1999. Plants products as antimicrobial agents. Clin Microbio Rew (12): 564-582.

5. Damintoti., K, Mamoudou., H D, Jacques., S, Alfred., S T (2005). Antioxidant and antimicrobial activities of polyphenols from ethanomedicine plants of Burkina Faso. African journal of Biotechnology 4(8): 823-828.

6. Khan, N.H., Nur-E, M.S.A., Kamal. and Rahman, M. (1988). Antibacterial activity of Euphorbia thymifolia. Linn. Indian Journal of Medicine and Research (87):395-397.

7. Gulnaz, A. R and Savitha, G (2013). Evaluation of antimicrobial activity of leaf and stem extracts of Sidda medicinal plant Sida cordata. International Journal of Medicine and Pharmaceutical Sciences. 3(3): 39-50.

8. Bauer, A.W., Kirby, W.M.M., Sheriss, J.C. and Turck, M. (1966). Antibiotic susceptibility testing by standard for anti-microbial susceptibility testing. $16^{\text {th }}$ Informational Supplement. M100-S16. Wayne, PA, USA: CLSI. 
9. NCCLS-National Committee for Clinical Laboratory Standards (2001).Performance Standards for an-microbial susceptibility testing: eleventh informational supplement. Document M100-S11, National Committee for Clinical Laboratory Standards, Wayne, PA, USA.

10. Brantner A., Grein E. Antibacterial activity of plant extracts used externally in traditional medicine. (1994). J. Ethnopharm. 44(1):35-40.

11. Oloyede, O. B., Salau, A. K., Akeusola, R. T., Ganiyu, O. T., Azeez, L., Ogunbode, S. M (2012). Phytochemical content, Radical Scavenging and Antibacterial properties of aqueous extract of Jatropa curcas Lin leaces. Fountain Journal of Natural and Applied Sciences. 1(1): 41-48.

12. Kamaraj, C., Rahuman, A. D., Siva, Kirthi, A. V (2012). Evaluation of Antibacterial activity of selected medicinal plant extracts from south India against human pathogens. Asian Pacific Journal Journal of Tropical Disease. S296-S301.

13. Sen, A., and Batra. (2012). Evaluation of antimicrobial activity of different solvent extracts of medicinal plants: Melia Azedarach L. International Journal of Current Pharmaceutical Research (4):67-73.

14. Thomas, J Webster (2012). Antimicrobial applications of nanotechnology methods and literature. International Journal of Nanomedicine. (7): 2767-2781.

15. Aladesanmi, A.J., Safowora, A. and Leary, J.D. (1986). Preliminary biological and phytochemical investigation of two Nigerian medicinal plants. International Journal of Crude Drug Research (24):147-153.

16. Al-Saleh, F.S., Gamal, A.Y., EL-Din, Abbar, J.A. and Saeed, N.A. (1997). Phytochemical and biological studies of medicinal plants in Bahrain: Family chenopodiaceae part 2. International Journal of Pharmacogenesis (35):38-42.

17. Singh, R.K. and Nath, G. (1999). Antimicrobial activity of Elaccocarpus sphaericus. Phytotherapy Research (13):448-450.

18. Quarenghi, M.V., Tereschuk, M.C., Baigori, M.D. and Abdala, L.R. (2000). Antimicrobial activity of flowers from Anthemis cotula. Fitoterapsia (71):710-712.

19. Torrenegra, R.D., Kocabae, E.E., Bedir, E., Sukan, F.V., Ozek, T. and Baser, K.H.C. (2007). Antimicrobial activities of methanol extracts and essential oils of Rosmarinus officinalis, depending on location and seasonal variation. Food Chemistry (100):553-559.

20. Toroglu, S. (2011). In-Vitro antimicrobial activity and synergistic/antagonistic effect of interactions between antibiotics and some spice essential oils. Journal of Environmental Biology. 32(1):23-29.

21. Dahikar, S.D., Bhutada, S.A., T ambekar, D.H., Vibhute, S.K. and Kasture, S.B. (2011). In-vitro antibacterial efficacy of solvent extracts of leaves of Bauhinia racemosa Lam. (Caesalpiniaceae) against enteric bacterial pathogens. International Journal of Pharmaceutical Sciences and Drug Research (3):31-34.

22. Tambekar, D.H., Jaitalkar, D.S. and Kavitkar, M.V. (2012). Studies on antimicrobial potential of medicinal plants from Lonar lake. Science Research Reporter (2):268-273.

23. Prasannabalaji, N., Muralitharan, G., Sivanandan, R.N., Kumaran, S. and Pugazhvendan, S.R. (2012). Antibacterial activities of some Indian traditional plant extracts. Asian Pacific Journal of Tropical Disease S291-S295.

24. Zubair, M., Rizwan, K., Rasool, N., Afshan, N., Shahid, M. and Ahmed, V.U. (2011). Antimicrobial potential of various extracts and fractions of leaves of Solanum nigrum. International Journal of Phytomedicine (3):63-67.

25. Kavitha, K.S. and Satish, S. 2013. Evaluation of antimicrobial and antioxidant activity from Toona ciliatoc Roemer. Journal of Analytical Science and Technology 4(1): 23-27 
Table 1: Zone of inhibitory activity (in millimeter) of different solvent extracts of $S$. xantocarpum fruit against the test bacteria well method $(0.5$ and $0.75 \mathrm{mg})$.

\begin{tabular}{|l|l|l|l|l|l|l|l|}
\hline Solvent extract & $\mathrm{mg}$ & E. coli & Proteus & Klebsiella & Pseudomonas & Enterobacter & S.aureus \\
\hline Aqueous & 0.5 & 00 & 00 & 00 & 00 & 00 & 00 \\
\hline & 0.7 & 00 & 00 & 00 & 00 & $9.6 \pm 0.3^{\mathrm{a}}$ & $12.6 \pm 0.3^{\mathrm{a}}$ \\
\hline Ethanol & 0.5 & 00 & 00 & 00 & 00 & 00 & 00 \\
\hline & 0.7 & $11.0 \pm 0.5^{\mathrm{a}}$ & $12.3 \pm 0.8^{\mathrm{a}}$ & 00 & $9.6 \pm 0.8^{\mathrm{a}}$ & $18.0 \pm 0.5^{\mathrm{a}}$ & 00 \\
\hline Ethyl acetate & 0.5 & $11.3 \pm 0.8^{\mathrm{a}}$ & 00 & 00 & 00 & 00 & 00 \\
\hline & 0.7 & $14.3 \pm 0.5^{\mathrm{a}}$ & 00 & $11.0 \pm 0.5^{\mathrm{a}}$ & $11.6 \pm 0.8^{\mathrm{a}}$ & 00 & $11.0 \pm 0.5^{\mathrm{a}}$ \\
\hline Pet ether & 0.5 & 00 & 00 & 00 & 00 & 00 & 00 \\
\hline Chloroform & 0.7 & 00 & 00 & 00 & 00 & 00 & 00 \\
\hline & 0.5 & 00 & 00 & 00 & 00 & 00 & 00 \\
\hline Kanamycin & 30 & $10.0 \pm 0.0^{\mathrm{a}}$ & 00 & $8.0 \pm 0.0^{\mathrm{a}}$ & 00 & 00 & 00 \\
\hline
\end{tabular}

0.5 and $0.75 \mathrm{mg} / \mathrm{ml}$ concentration of the extract used

Values are means of three independent replicates

Mean values with different superscripts are significantly different from each other as indicated by Tukey’s HSD (P $\leq 0.05$ ) 


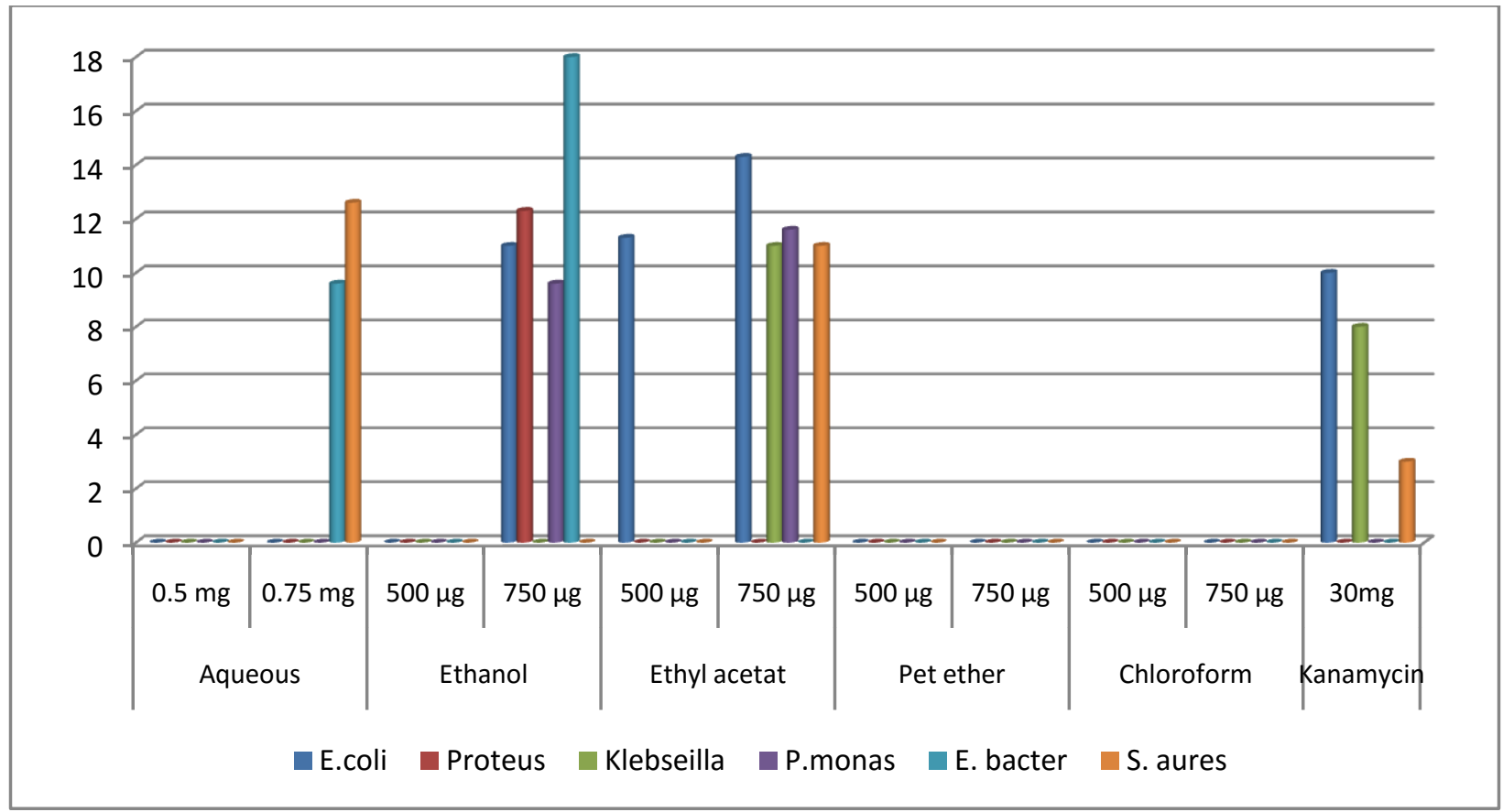

Fig 1: Antibacterial activity of $S$. xantocarpum fruit by well method 


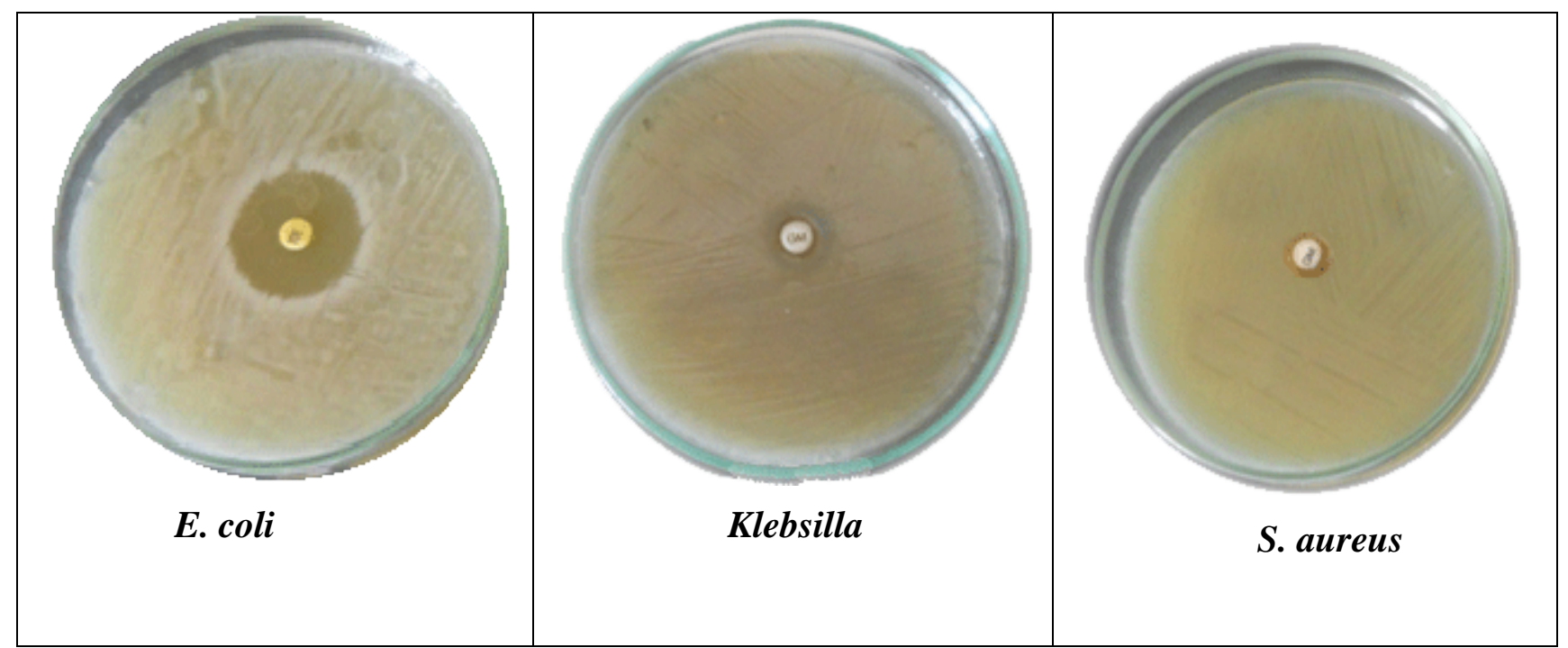

Figure 1a: Antibacterial activity of the standard antibiotic Kanamycine $30 \mathrm{mg} /$ disc against the test bacteria (a) E. coli (b) Klebsilla (c) S. aureus.

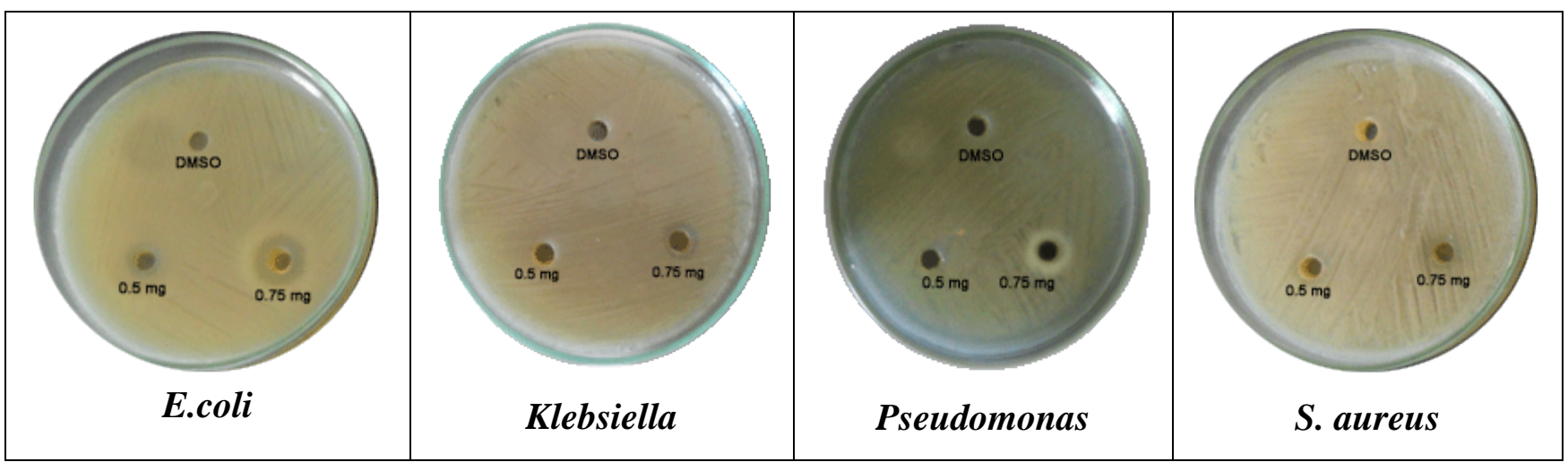

Figure 1b: Ethyl acetate extract of $S$. xantocarpum (Fruit) by well method. 
Table 2: Zone of inhibitory activity (in millimeter) of different solvent extracts of $S$. xantocarpum fruit against the test bacteria well method (0.1 and $0.2 \mathrm{mg})$.

\begin{tabular}{|c|c|c|c|c|c|c|c|}
\hline Solvent extract & $\mathrm{mg}$ & E. coli & Proteus & Klebsiella & Pseudomonas & Enterobacter & S.aureus \\
\hline \multirow[t]{2}{*}{ Aqueous } & 0.01 & 00 & 00 & 00 & 00 & 00 & 00 \\
\hline & 0.02 & 00 & $6.0 \pm 0.57^{\mathrm{a}}$ & 00 & 00 & 00 & 00 \\
\hline \multirow[t]{2}{*}{ Ethanol } & 0.01 & 00 & 00 & 00 & 00 & 00 & 00 \\
\hline & 0.02 & 00 & 00 & $3.6 \pm 0.33^{b}$ & 00 & 00 & $8.0 \pm 0.57^{\mathrm{a}}$ \\
\hline \multirow[t]{2}{*}{ Ethyl acetate } & 0.01 & 00 & 00 & 00 & 00 & 00 & 00 \\
\hline & 0.02 & 00 & 00 & 00 & 00 & 00 & 00 \\
\hline \multirow[t]{2}{*}{ Pet ether } & 0.01 & 00 & 00 & 00 & 00 & 00 & 00 \\
\hline & 0.02 & 00 & 00 & 00 & 00 & 00 & 00 \\
\hline \multirow[t]{2}{*}{ Chloroform } & 0.01 & 00 & 00 & 00 & 00 & 00 & 00 \\
\hline & 0.02 & 00 & 00 & 00 & & 00 & 00 \\
\hline Kanamycin & 30 & $10.0 \pm 0.0^{\mathrm{a}}$ & 00 & $8.0 \pm 0.0^{\mathrm{a}}$ & 00 & 00 & $3.0 \pm 0.0^{\mathrm{a}}$ \\
\hline
\end{tabular}

0.01 and $0.02 \mathrm{mg} / \mathrm{ml}$ concentration of the extract used

Values are means of three independent replicates

Mean values with different superscripts are significantly different from each other as indicated by Tukey's HSD (P $\leq 0.05$ ) 


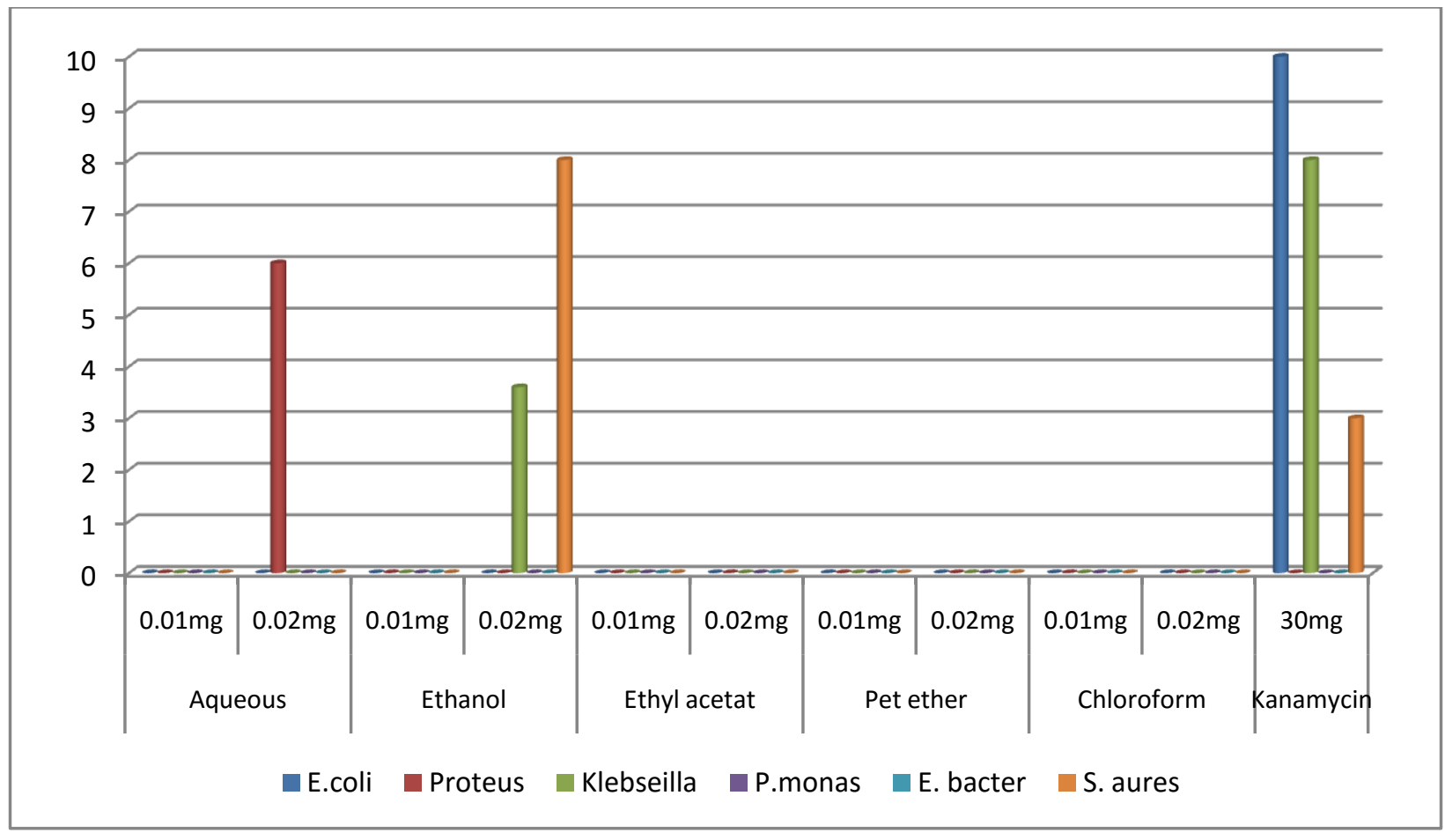

Fig 2a: Antibacterial activity of $S$. xantocarpum fruit by disc method. 
Figure 2b: Alcoholic extract of $S$. xantocarpum (Fruit) by well method

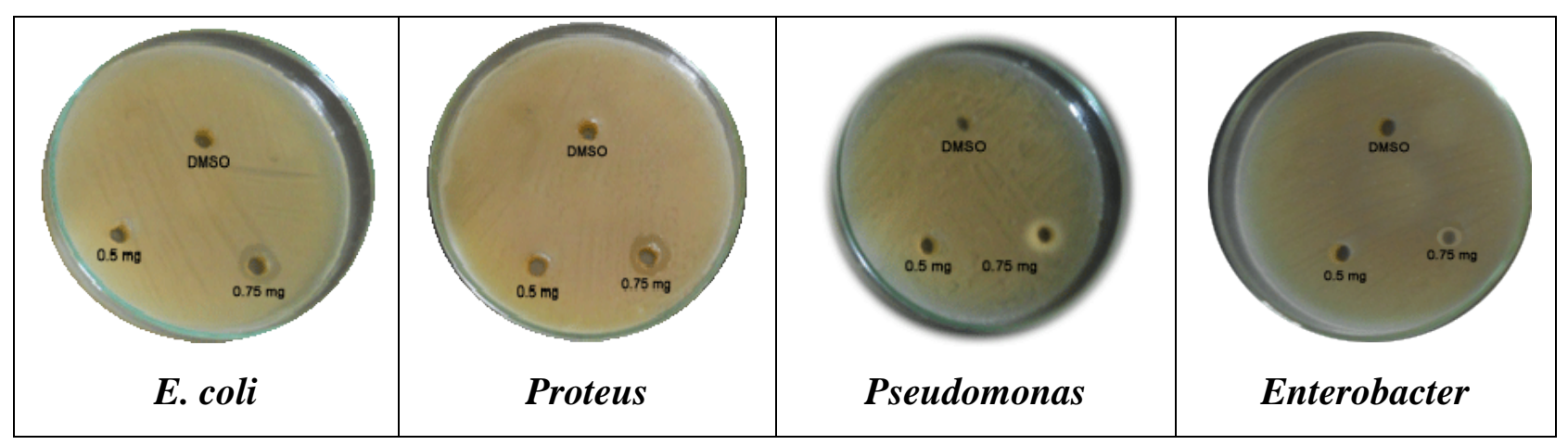

Table 3: Minimum Inhibitory Concentration (MIC) of S. xanthocarpum fruit of alcohol and ethyl acetate extract using broth dilution method against pathogens at different concentration $(\mathrm{mg} / \mathrm{ml})$.

\begin{tabular}{|l|l|l|l|l|l|l|l|}
\hline \multicolumn{2}{|l|}{ Organism } & $\begin{array}{l}\text { E. } \\
\text { coli }\end{array}$ & Proteus & Klebsilla & Pseudomonas & Enterobacter & S.aureus \\
\hline $\begin{array}{l}\text { S.xanthocarpam. } \\
\text { fruit }\end{array}$ & Alcohol & 0.5 & 0.5 & 0.5 & 00 & 0.75 & 0.125 \\
\cline { 2 - 8 } & Ethylacetate & 0.67 & 00 & 0.75 & 0.5 & 00 & 0.5 \\
\hline Kanamycin & 0.125 & 00 & 0.125 & 00 & 00 & 00 \\
\hline
\end{tabular}


Fig 3a: Minimum inhibitory concentrations (MIC) of $S$. xanthocarpum fruit of alcohol and ethyl acetate extract against pathogens at different concentration $(\mathrm{mg} / \mathrm{ml})$.

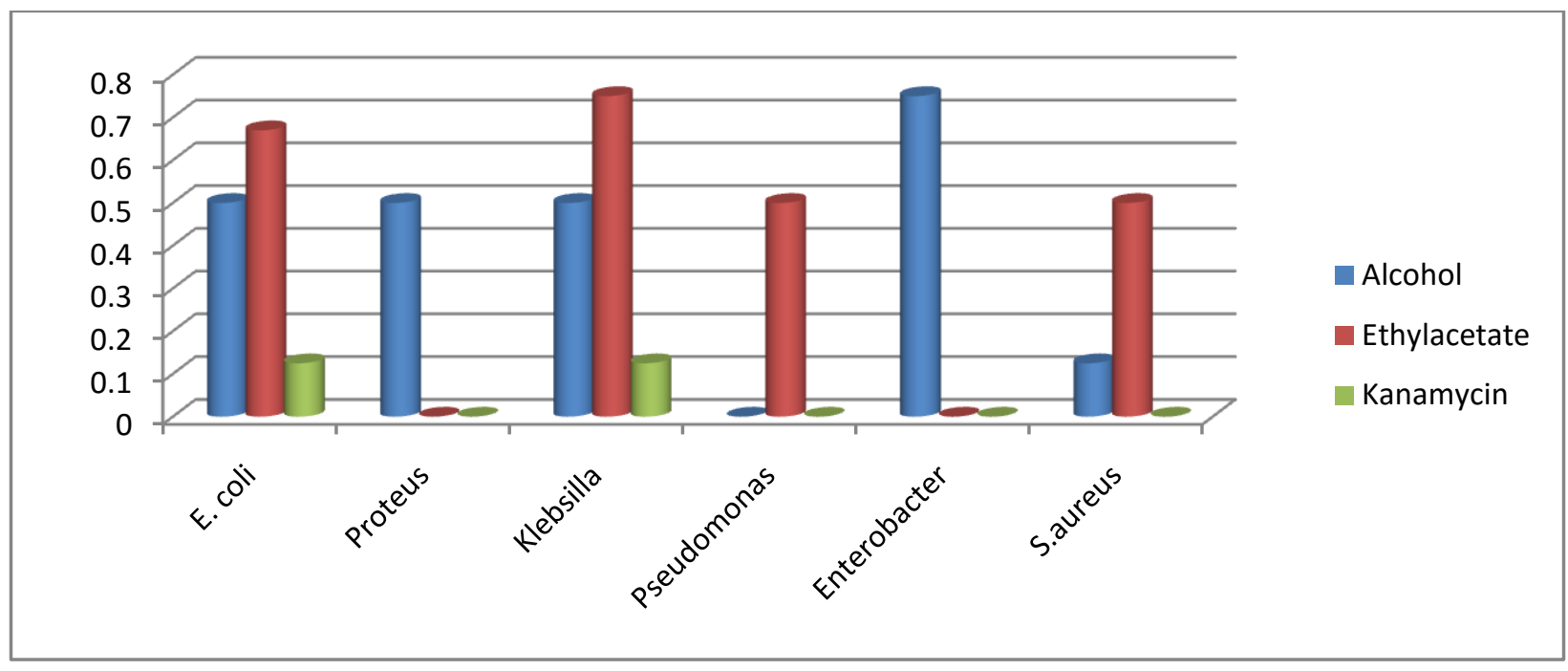

